
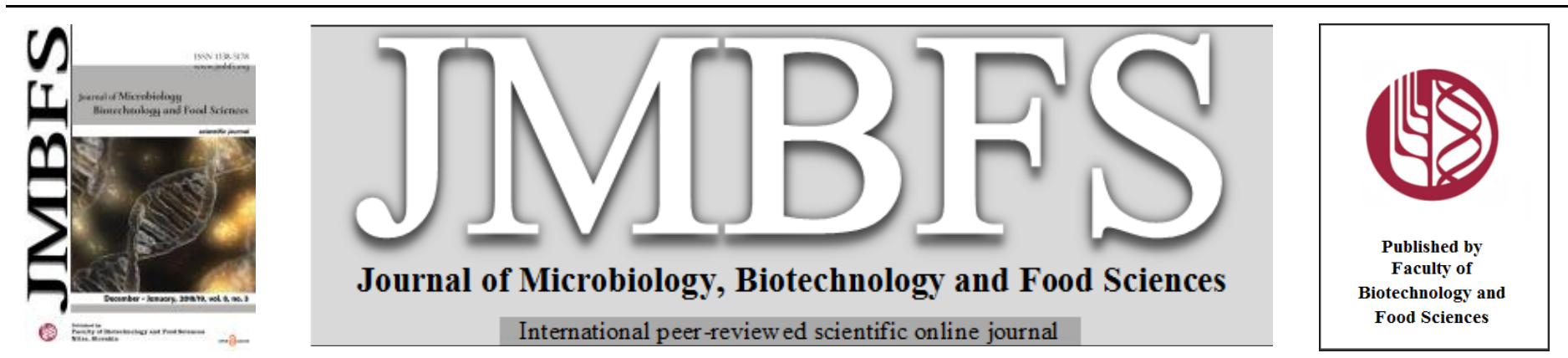

\title{
THE EFFICIENCY OF IMMUNOMAGNETIC SORTING OF RABBIT BONE MARROW CELLS FOR THE ESTABLISHMENT OF MESENCHYMAL STEM CELL CULTURE
}

\author{
Jaromir Vašiček ${ }^{* 1,2}$, Andrej Baláži ${ }^{1}$, Peter Chrenek ${ }^{1,2}$ \\ Address(es): Ing. Jaromír Vašíček, PhD. \\ ${ }^{1}$ National Agricultural and Food Centre, Research Institute for Animal Production Nitra, Hlohovecká 2, 95141 Lužianky, Slovak Republic, +421 376546121. \\ ${ }^{2}$ Slovak University of Agriculture in Nitra, Faculty of Biotechnology and Food Sciences, Department of Biochemistry and Biotechnology, Tr. A. Hlinku 2, 94976 \\ Nitra, Slovak Republic.
}

*Corresponding author: jaromir.vasicek@gmail.com

doi: 10.15414/jmbfs.2018/19.8.3.890-892

\section{ARTICLE INFO}

Received 3. 7. 2018

Revised 24. 9. 2018

Accepted 24. 9. 2018

Published 1. 12. 2018

Regular article

open $\partial_{\text {ACCESS }}$

\begin{abstract}
The aim of this study was to assess if immunomagnetic sorting of SSEA-4 or MSCA-1 positive bone marrow cells could facilitate and expedite the establishment of rabbit MSCs culture. Briefly, rabbit bone marrow cells were enriched for SSEA $-4^{+}$and MSCA- $1^{+}$cells using two clones of SSEA-4 antibodies (REA101 and MC-813-70) and MSCA-1 antibody (clone W8B2) via magnetic-activated cell sorting. Flow-cytometric analysis revealed a high level of sorting efficiency, since the SSEA- $4^{+}$cells were significantly $(\mathrm{P}<0.001)$ enriched from 17 to $95 \%$ and MSCA- $1^{+}$cells from 8 to $74 \%$. According to morphological changes, both sorted fractions (positive and negative) successfully initiate rabbit MSCs culture, but not expedite the proliferation rate as compared to standard MSCs culture initiated from unsorted cells. Moreover, all samples (sorted and unsorted) expressed high levels of the typical MSCs markers (CD29 and CD44) and low expression of hematopoietic marker CD45. In conclusion, although this study revealed the possibility to enrich SSEA-4 $4^{+}$ and MSCA- $1^{+}$positive cells from the rabbit bone marrow, the standard method of MSCs isolation using the plastic adherent ability of the unsorted bone marrow cells seems to be still useful and less cost effective.
\end{abstract}

Keywords: rabbit, MSCs, MACS, SSEA-4, MSCA-1, plastic adherence

\section{INTRODUCTION}

The method of plastic adherence became a standard technique for the isolation of human (Pittenger et al., 1999), mouse (da Silva Meirelles et al., 2006) or rabbit mesenchymal stem cells (MSCs) from the different biological sources such as bone marrow (Sahoo et al., 2010), adipose tissue (Sun $\boldsymbol{e t}$ al., 2016) or amniotic fluid (Kovac et al., 2017). However, in the recent years new technique has been established to facilitate the isolation of mesenchymal stromal or stem cells via magnetic-activated cell sorting (MACS) or fluorescence-activated cell sorting (FACS). This method allows to obtain enriched human clonogenic (CFU-F) MSCs subsets directly from the heterogeneous cell populations based on the expression of specific antigen such as STRO-1 (Gronthos and Simmons, 1995), MSCA-1 (Batulla et al., 2009) or CD271 (Quirici et al., 2002). The CFU-F fraction of bone marrow is considered to be the precursor or stem cell that resides in the bone marrow (primary MSCs) from which culture-expanded MSCs originate (Rozemuller et al., 2010). Recently, SSEA-4 was also found to be expressed by human MSCs (Gang et al., 2007) that can be as well used to enrich the bone marrow CFU-F cell fraction (Rozemuller et al., 2010). MSCA-1, mesenchymal stem cell antigen-1, was shown to be identical to tissue-nonspecific alkaline phosphatase, an ectoenzyme known to be expressed at high levels in liver, bone, and kidney as well as in embryonic stem cells (Sobiesiak $\boldsymbol{e t}$ al., 2009). SSEA-4, stage specific embryonic antigen-4, previously found specifically on human embryonic stem cells and very early cleavage to blastocyst stage embryos (Thomson et al., 1998), was found also on induced pluripotent cells (Valamehr et al., 2012), embryonal carcinoma cells (Kannagi et al., 1983), and embryonic germ cells (Shamblott $\boldsymbol{e t}$ al., 1998) as well as a variety of somatic stem cells, such as dental pulp stem cells, umbilical cord blood-derived very small embryonic like stem cells (Bhartiya et al., 2012) and as mentioned above also MSCs (Gang et al., 2007). The objective of this study was to assess if immunomagnetic sorting of SSEA-4 or MSCA-1 positive bone marrow cells could facilitate and expedite the establishment of rabbit MSCs culture.

\section{MATERIAL AND METHODS}

Isolation and immunomagnetic sorting of rabbit bone marrow mononuclear cells (BMMCs)

Rabbit BMMCs were isolated from 16 young (5 months-old) and clinically health rabbits of NZW line as described previously (Vašíček et al., 2016). BMMCs were divided into control (fresh unsorted) cells and cells intended for MACS sorting as described below. Briefly, BMMCs were incubated with two different clones of monoclonal PE-conjugated SSEA-4 antibodies (REA101 from Miltenyi Biotec, Germany; and MC-813-70 from eBioscience, Austria) and PE-conjugated MSCA-1 antibody (clone W8B2 from Miltenyi Biotec, Germany) according to the producer's manual. After washing, samples were incubated with Anti-PE MicroBeads (Miltenyi Biotec, Germany) and then sorted using AutoMACS Pro Separator (Miltenyi Biotec, Germany) according to the producer's manual Positive selection in sensitive mode "POSSEL_S" was applied in order to sort rare cells with a low antigen expression

\section{Culturing of fresh rabbit BMMCs and sorted MSCs}

Briefly, fresh BMMCs or sorted cells from negative (SSEA-4- and MSCA-1 ${ }^{-}$) and positive $\left(\mathrm{SSEA}-4^{+}\right.$and $\mathrm{MSCA}-1^{+}$) fractions were resuspended in $20 \% \mathrm{MEM}$ Alpha medium (Thermo Fisher Scientific, USA) with supplements and then plated at density of $1.2-1.5 \times 10^{6}$ cells $/ \mathrm{cm}^{2}$ (fresh BMMCs) or at density of $0.3-$ $0.5 \times 10^{5}$ cells $/ \mathrm{cm}^{2}$ (sorted cells) on appropriate tissue culture flasks. Morphology of cultured cells was visualized by Zeiss Primovert phase-contrast microscopy (Carl Zeiss Slovakia, Slovakia). The rate of cell proliferation of each sample was assessed as the length of culture (days) when cells achieve first confluency (about 80-90\%). Cells were cultured approximately 3-4 weeks till the passage 3. MSCs were then dissociated using $0.05 \%$ Trypsin-EDTA (Thermo Fisher Scientific, USA) and analysed for the MSCs phenotype using flow cytometry.

\section{Flow cytometry analysis}

Control samples of BMMCs were analysed for initial SSEA-4 and MSCA-1 expression using above mentioned antibodies, but not sorted. Aliquots of sorted 
samples before seeding were analysed for the purity and efficiency of MACS sorting in terms of the percentage of SSEA-4 $4^{+}$and MSCA- $1^{+}$cells in both fractions. MSCs phenotype of cultured cells at passage 3 was confirmed by incubation with following monoclonal antibodies: FITC-conjugated CD29 (clone P4G11 from Merck, Slovak Republic), unconjugated CD44 (IgG1, clone W4/86) and CD45 (IgG1, clone L12/201, both from Bio-Rad, UK) and appropriate FITCconjugated anti-mouse IgG1 secondary antibody (clone M1-14D12 from eBioscience, Austria). 7-AAD (eBioscience, Austria) was used in order to exclude debris and dead cells from the analysis. Labelled cells before and after sorting were evaluated using the FACSCalibur flow cytometer (BD Biosciences, USA). At least 50,000 events (cells) were analysed in each sample.

\section{Statistical analysis}

The experiments were replicated three times. Observed results were evaluated statistically using one-way ANOVA (Holm-Sidak method) by SigmaPlot software (Systat Software Inc., Germany) and expressed as the means \pm SEM. Pvalues at $\mathrm{P}<0.05$ were considered as statistically significant.

\section{RESULTS AND DISCUSSION}

\section{MACS sorting}

In this study, we found out that about $20 \%$ of fresh rabbit bone marrow cells showed the positivity for SSEA-4 antigen and less than $10 \%$ positivity for MSCA-1 antigen (Tab 1). The small proportion of SSEA- $4^{+}$cells have been previously reported in human bone marrow (2-4\%, Gang et al., 2007). Moreover, SSEA-4 expression was found on the human and murine (Gang et al., 2007), monkey and goat (Rozemuller et al., 2010) as well as on the rabbit MSCs (Ding and Huang, 2015). Similarly, MSCA-1 antigen was previously detected on human $(0.9 \pm 0.4 \%)$, monkey $(9.4 \pm 4.9 \%)$, goat $(2.2 \pm 1.2 \%), \operatorname{dog}(5.5 \pm 4.2 \%)$, pig $(3.9 \pm 6.8 \%)$ and sheep $(19.2 \pm 15.4 \%)$ BMMCs as well as on the MSCs of mentioned species (Rozemuller et al., 2010). Furthermore, the MACS technique revealed a high level of sorting efficiency, since this method significantly $(\mathrm{P}<0.001)$ enriched the population of SSEA-4 ${ }^{+}$cells (from 17 to $95 \%$, Tab 1 ). Also population of $\mathrm{MSCA}-1^{+}$cells was significantly enriched by the positive immunomagnetic selection (from 8 to $74 \%$, Tab 1). Thus, we could assume that enrichment and seeding of SSEA $-4^{+}$or $\mathrm{MSCA}-1^{+} \mathrm{BMMCs}$ could give rise to whole rabbit clonogenic MSCs culture. To confirm this assumption, sorted cells from both fractions and unsorted fresh rabbit BMMCs (served as control) were seeded and cultured as described above or elsewhere.

Table 1 Sorting efficiency of MACS enriched (SSEA- $4^{+}$and MSCA- ${ }^{+}$) bone marrow cells assessed by flow cytometry

\begin{tabular}{llll}
\hline Marker & $\begin{array}{l}\text { Before MACS } \\
(\%)\end{array}$ & $\begin{array}{l}\text { MACS Negative } \\
\text { Fraction (\%) }\end{array}$ & $\begin{array}{l}\text { MACS Positive } \\
\text { Fraction (\%) }\end{array}$ \\
\hline $\begin{array}{l}\text { SSEA-4 } \\
(\text { REA101) }\end{array}$ & $17.74 \pm 1.64^{\mathrm{b}}$ & $1.52 \pm 0.05^{\mathrm{b}}$ & $90.31 \pm 4.07^{\mathrm{a}}$ \\
\hline $\begin{array}{l}\text { SSEA-4 (MC- } \\
813-70)\end{array}$ & $25.64 \pm 0.56^{\mathrm{b}}$ & $1.97 \pm 0.08^{\mathrm{b}}$ & $95.67 \pm 0.01^{\mathrm{a}}$ \\
\hline MSCA-1 (W8B2) & $8.58 \pm 2.08^{\mathrm{b}}$ & $2.10 \pm 0.20^{\mathrm{b}}$ & $73.63 \pm 7.45^{\mathrm{a}}$ \\
\hline $\begin{array}{l}\text { Legend: Results are expressed as mean values } \pm \text { SEM. Different letters indicate significant } \\
\left.\text { differences ( }{ }^{\mathrm{a}} \text { vs }{ }^{\mathrm{b}} \text { at } \mathrm{P}<0.001\right) \text { among the means in each line. }\end{array}$
\end{tabular}

\section{Cell morphology and growth rate}

Morphological changes of cultured unsorted or sorted cells confirmed successful initiation of rabbit MSC culture. However, the growth rate of sorted (nor negative neither positive) cells did not significantly differ from the proliferation of fresh unsorted BMMCs, since all samples required approximately 14-19 days in order to reach $80-90 \%$ cell confluency after initial seeding (Tab 2). Moreover, cells in all samples showed typical fibroblastic-like morphology with a spindle shape (Fig 1A-D). On the contrary, Gang et al. (2007) noticed that human SSEA-4 cells failed to grow, whereas SSEA- $4^{+} \mathrm{CD} 45^{-}$cells adhered to the plastic and produced a homogeneous cell-monolayer characteristic of MSCs. Moreover, they observed that an equivalent number of unsorted bone marrow cells plated at the same cell density did not successfully initiate MSC cultures. Such cultures could only be derived from higher densities of unsorted cells as was confirmed by higher seeding density of fresh rabbit BMMCs in our study (Fig 1D). On the other hand, Batulla et al. (2009) successfully initiate the human MSC culture also from the MSCA-1 $1^{+}$and $\mathrm{CD} 271^{+}$sorted bone marrow cells. Furthermore, culture of $\mathrm{CD} 271^{+}\left(\mathrm{LNGFR}^{+}\right)$sorted bone marrow cells could by more effective in the terms of growth rate of MSCs than the culture of unsorted heterogeneous cell population isolated from bone marrow (Quirici $\boldsymbol{e t}$ al., 2002).

Table 2 Rate of cell proliferation assessed as the time period required for the achieving of first confluency $(80-90 \%)$

\begin{tabular}{|c|c|c|c|c|c|c|c|}
\hline \multirow[t]{2}{*}{ Sample } & \multicolumn{2}{|c|}{ SSEA-4 (REA101) } & \multicolumn{2}{|c|}{ SSEA-4 (MC-813-70) } & \multicolumn{2}{|c|}{ MSCA-1 (W8B2) } & \multirow{2}{*}{$\begin{array}{l}\text { Unsorted } \\
\text { BMMCs }\end{array}$} \\
\hline & $\begin{array}{l}\text { Negative } \\
\text { fraction }\end{array}$ & $\begin{array}{l}\text { Positive } \\
\text { fraction }\end{array}$ & $\begin{array}{l}\text { Negative } \\
\text { fraction }\end{array}$ & $\begin{array}{l}\text { Positive } \\
\text { fraction }\end{array}$ & $\begin{array}{l}\text { Negative } \\
\text { fraction }\end{array}$ & $\begin{array}{l}\text { Positive } \\
\text { fraction }\end{array}$ & \\
\hline Time period & $17 \pm 3$ & $17 \pm 1$ & $18 \pm 1$ & $17 \pm 1$ & $14 \pm 1$ & $19 \pm 1$ & $15 \pm 4$ \\
\hline
\end{tabular}

Legend: Results are expressed as mean values \pm SEM.

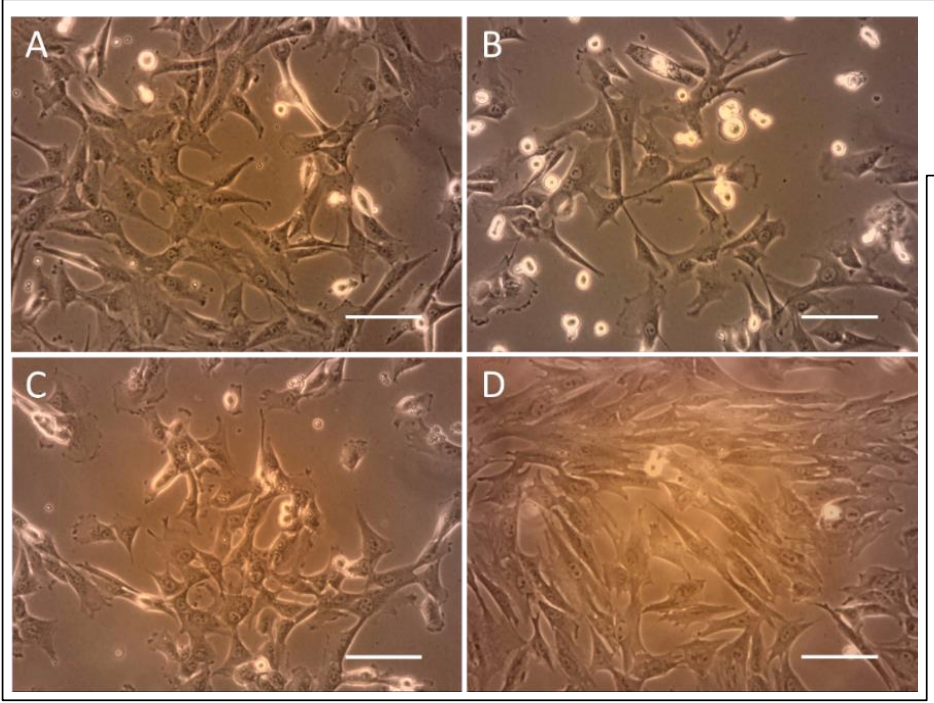

Figure 1 Illustrative morphology images of the cultured unsorted and MACS enriched (SSEA-4 ${ }^{+}$and MSCA- $1^{+}$) bone marrow cells. A) Cells sorted using SSEA-4 (REA101); B) Cells sorted using SSEA-4 (MC-813-70); C) Cells sorted using MSCA-1 (W8B2); D) Unsorted cells seeded immediately after isolation; $100 \times$ magnification; Scale bars $=200 \mu \mathrm{m}$

\section{MSCs phenotyping}

Flow-cytometric analyses (Tab 3) confirm the typical MSCs phenotype of all samples (sorted or unsorted), since cells showed high positivity for CD29 and CD44, and were negative for hematopoietic lineage marker CD45. Although in some samples (SSEA-4: MC-813-70 ${ }^{+}$and MC-813-70 ${ }^{+}$, and MSCA- ${ }^{+}$) the purity of MSCs were significantly decreased $(\mathrm{P}<0.001$, Tab 3$)$ by the contamination with hematopoietic $\left(\mathrm{CD} 45^{+}\right)$cells in comparison to other analysed samples, the majority of these cells still expressed typical rabbit MSCs markers and morphology as observed by other studies (Tan et al., 2013; Lee et al., 2014).

\begin{tabular}{|c|c|c|c|c|c|c|c|}
\hline \multirow{2}{*}{$\begin{array}{l}\text { Sample/ } \\
\text { Marker (\%) }\end{array}$} & \multicolumn{2}{|c|}{ SSEA-4 (REA101) } & \multicolumn{2}{|c|}{ SSEA-4 (MC-813-70) } & \multicolumn{2}{|c|}{ MSCA-1 (W8B2) } & \multirow{2}{*}{$\begin{array}{l}\text { Unsorted } \\
\text { BMMCs }\end{array}$} \\
\hline & $\begin{array}{l}\text { Negative } \\
\text { fraction }\end{array}$ & Positive fraction & $\begin{array}{l}\text { Negative } \\
\text { fraction }\end{array}$ & $\begin{array}{l}\text { Positive } \\
\text { fraction }\end{array}$ & $\begin{array}{l}\text { Negative } \\
\text { fraction }\end{array}$ & $\begin{array}{l}\text { Positive } \\
\text { fraction }\end{array}$ & \\
\hline CD29 & $72.13 \pm 6.54$ & $74.82 \pm 12.45$ & $82.76 \pm 8.94$ & $72.54 \pm 1.89$ & $86.96 \pm 0.87$ & $78.62 \pm 1.09$ & $94.36 \pm 4.05$ \\
\hline CD44 & $89.15 \pm 2.14$ & $95.86 \pm 1.47$ & $78.84 \pm 12.87$ & $78.77 \pm 2.98$ & $96.74 \pm 1.18$ & $89.07 \pm 1.52$ & $92.12 \pm 2.16$ \\
\hline CD45 & $2.23 \pm 0.36^{\mathrm{b}}$ & $1.7 \pm 0.10^{\mathrm{b}}$ & $10.03 \pm 0.03^{\mathrm{a}}$ & $10.03 \pm 0.51^{\mathrm{a}}$ & $3.90 \pm 1.95^{\mathrm{b}}$ & $9.35 \pm 0.23^{\mathrm{a}}$ & $3.79 \pm 1.73^{\mathrm{b}}$ \\
\hline
\end{tabular}

Legend: Results are expressed as mean values \pm SEM. Different letters indicate significant differences $\left({ }^{\mathrm{a}} \mathrm{vs}{ }^{\mathrm{b}}\right.$ at $\left.\mathrm{P}<0.001\right)$ among the means in each line. 


\section{CONCLUSION}

The present study revealed the possibility to enrich SSEA- $4^{+}$and MSCA- ${ }^{+}$ positive cells from the rabbit bone marrow. These cells successfully initiated the MSCs culture after seeding as confirmed by the typical morphology and phenotype of mesenchymal stem cells. However, these technique was not more efficient in the terms of MSCs proliferation rate in comparison to the culture initiated from the fresh isolated heterogeneous bone marrow cells. Thus, the standard method of MSCs isolation using the plastic adherent ability of these cells seems to be still useful and less cost effective than the immunomagnetic sorting of small bone marrow fractions. On the other hand, further experiments are required in order to examine if more specific sorting of bone marrow cells by the depleting of $\mathrm{CD}_{4} 5^{+}$cells from the SSEA- $4^{+}$and $\mathrm{MSCA}-1^{+}$enriched fractions, could bring really pure populations of rabbit MSCs.

Acknowledgments: This work was supported by the grants of Slovak Research and Development Agency: APVV-14-0043 and APVV-14-0348 and the Scientific Grant Agency of the Ministry of Education, science, research and sport of the Slovak Republic and the Slovak Academy of Sciences: VEGA 1/0611/15 and VEGA 1/0160/18 and KEGA 026SPU-4/2018.

\section{REFERENCES}

BATTULA, V.L., TREML, S., BAREISS, P.M., GIESEKE, F., ROELOFS, H., DE ZWART, P., MÜLLER, I., SCHEWE, B., SKUTELLA, T., FIBBE, W.E., KANZ, L., BÜHRING, H.J. 2009. Isolation of functionally distinct mesenchymal stem cell subsets using antibodies against CD56, CD271, and mesenchymal stem

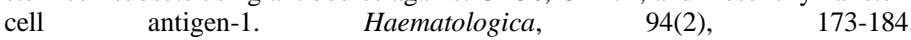
https://doi.org/10.3324/haematol.13740

BHARTIYA, D., SHAIKH, A., NAGVENKAR, P., KASIVISWANATHAN, S., PETHE, P., PAWANI, H., MOHANTY, S., RAO, S.G., ZAVERI, K., HINDUJA, I. 2012. Very small embryonic-like stem cells with maximum regenerative potential get discarded during cord blood banking and bone marrow processing for autologous stem cell therapy. Stem cells and development, 21(1), 1-6. https://doi.org/10.1089/scd.2011.0311

DA SILVA MEIRELLES, L., CHAGASTELLES, P.C., NARDI, N.B. 2006 Mesenchymal stem cells reside in virtually all post-natal organs and tissues. Journal of Cell Science, 119(Pt 11), 2204-2213. https://doi.org/10.1242/jcs.02932 DING, Z., HUANG, H. 2015. Mesenchymal stem cells in rabbit meniscus and bone marrow exhibit a similar feature but a heterogeneous multi-differentiation potential: superiority of meniscus as a cell source for meniscus repair. $B M C$ Musculoskeletal Disorders, 16, 65. https://doi.org/10.1186/s12891-015-0511-8

GANG, E.J., BOSNAKOVSKI, D., FIGUEIREDO, C.A., VISSER, J.W., PERLINGEIRO, R.C. 2007. SSEA-4 identifies mesenchymal stem cells from bone marrow. Blood, 109(4), 1743-1751. https://doi.org/10.1182/blood-2005-11$\underline{010504}$

GRONTHOS, S., SIMMONS, P.J. 1995. The growth factor requirements of STRO-1-positive human bone marrow stromal precursors under serum-deprived conditions in vitro. Blood, 85(4), 929-940.

KANNAGI, R., COCHRAN, N.A., ISHIGAMI, F., HAKOMORI, S. ANDREWS, P.W., KNOWLES, B.B., SOLTER, D. 1983. Stage-specific embryonic antigens (SSEA-3 and -4) are epitopes of a unique globo-series ganglioside isolated from human teratocarcinoma cells. The EMBO journal, 2(12), 2355-2361.

KOVAC, M., VASICEK, J., KULIKOVA, B., BAUER, M., CURLEJ, J., BALAZI, A., CHRENEK, P. 2017. Different RNA and protein expression of surface markers in rabbit amniotic fluid-derived mesenchymal stem cells. Biotechnology Progress, 33(6), 1601-1613. https://doi.org/10.1002/btpr.2519

LEE, T.C., LEE, T.H., HUANG, Y.H., CHENG, N.K., LIN, Y.J, CHANG CHIEN, P.W., YANG, W.H., LIN, M.H.C. 2014. Comparison of surface markers between human and rabbit mesenchymal stem cells. PLOS One, 9,e111390. https://doi.org/10.1371/journal.pone.0111390

PITTENGER, M.F., MACKAY, A.M., BECK, S.C., JAISWAL, R.K., DOUGLAS, R., MOSCA, J.D., MOORMAN, M.A., SIMONETTI, D.W., CRAIG, S., MARSHAK, D.R. 1999. Multilineage Potential of Adult Human Mesenchymal Stem Cells. Science, 284(5411), 143-147. https://doi.org/10.1126/science.284.5411.143

QUIRICI, N., SOLIGO, D., BOSSOLASCO, P., SERVIDA, F., LUMINI, C., DELILIERS, G.L. 2002. Isolation of bone marrow mesenchymal stem cells by anti-nerve growth factor receptor antibodies. Experimental Hematology, 30(7), 783-791. https://doi.org/10.1016/S0301-472X(02)00812-3

ROZEMULLER, H., PRINS, H.J., NAAIJKENS, B., STAAL, J., BÜHRING, H.J., MARTENS, A.C. 2010. Prospective isolation of mesenchymal stem cells from multiple mammalian species using cross-reacting anti-human monoclonal antibodies. Stem cells and development, 19(12), 1911-1921. https://doi.org/10.1089/scd.2009.0510

SAHOO, S., ANG, L.T., CHO-HONG GOH, J., TOH, S.L. 2010. Bioactive nanofibers for fibroblastic differentiation of mesenchymal precursor cells for ligament/tendon tissue engineering applications. Differentiation, 79(2), 102-110. https://doi.org/10.1016/j.diff.2009.11.001
SHAMBLOTT, M.J, AXELMAN, J., WANG, S., BUGG, E.M., LITTLEFIELD, J.W., DONOVAN, P.J., BLUMENTHAL, P.D., HUGGINS, G.R., GEARHART, J.D. 1998. Derivation of pluripotent stem cells from cultured human primordial germ cells. Proceedings of the National Academy of Sciences of the United States of America, 95(23), 13726-13731. https://doi.org/10.1073/pnas.95.23.13726

SOBIESIAK, M., SIVASUBRAMANIYAN, K., HERMANN, C., TAN, C., ORGEL, M., TREML, S., CERABONA, F., DE ZWART, P., OCHS, U., MÜLLER, C.A., GARGETT, C.E., KALBACHER, H., BÜHRING, H.J. 2009. The mesenchymal stem cell antigen MSCA-1 is identical to tissue nonspecific alkaline phosphatase. Stem cells and development, 19(5), 669-677. https://doi.org/10.1089/scd.2009.0290

SUN, W., NI, X., SUN, S., CAI, L., YU, J., WANG, J., NIE, B., SUN, Z., NI, X., CAO, X. 2016. Adipose-Derived Stem Cells Alleviate Radiation-Induced Muscular Fibrosis by Suppressing the Expression of TGF- $\beta 1$. Stem Cells International, 2016, 1-9. https://doi.org/10.1155/2016/5638204.

TAN, S.L., AHMAD, T.S., SELVERATNAM, L., KAMARUL, T. 2013 Isolation, characterization and the multilineage differentiation potential of rabbit bone marrow-derived mesenchymal stem cells. Journal of anatomy, 222(4), 437450. https://doi.org/10.1111/joa.12032

THOMSON, J.A., ITSKOVITZ-ELDOR, J., SHAPIRO, S.S., WAKNITZ, M.A. SWIERGIEL, J.J., MARSHALL, V.S., JONES, J.M. 1998. Embryonic stem cell lines derived from human blastocysts. Science, 282(5391), 1145-1147. https://doi.org/10.1126/science.282.5391.1145

VALAMEHR, B., ABUJAROUR, R., ROBINSON, M., LE, T., ROBBINS, D., SHOEMAKER, D., FLYNN, P. 2012. A novel platform to enable the highthroughput derivation and characterization of feeder-free human iPSCs. Scientific reports, 2, 213. https://doi.org/10.1038/srep00213

VAŠÍČEK, J., KOVÁČ, M., BALÁŽI, A., BAUER, M., CHRENEK, P. 2016. Phenotypic analysis of rabbit mesenchymal stem cells using flow cytometry and RT-PCR. Slovak Journal of Animal Science, 49(4), 160. 